\title{
A checklist of Egyptian fungi: I. Protozoan fungal analogues
}

\author{
Abdel-Azeem AM ${ }^{1} *$ and Salem Fatma $\mathbf{M}^{1}$ \\ ${ }^{1}$ Laboratory of systematic Mycology, Botany and Microbiology Department, Faculty of Science, University of Suez. \\ Canal, Ismailia 41522,Egypt.e-mail:zemo3000@yahoo.com,ahmed_abdelazeem@science.suez.edu.eg
}

Abdel-Azeem AM, Salem Fatma M 2013 - A checklist of Egyptian fungi: I. Protozoan fungal analogues. Mycosphere 4(4), 794-807, Doi 10.5943/mycosphere/4/4/15

\begin{abstract}
Records of Egyptian fungi are scattered through a wide array of journals, books, dissertations, and preliminary annotated checklists and compilations. By screening all available sources of information, it was possible to delineate 61 taxa, including 3 varieties, belonging to 29 genera of protozoan fungal analogues that have been reported from Egypt. A provisional key to the identification of reported taxa is given. This is the first species list of protozoan fungus-like analogues from Egypt.
\end{abstract}

Key words - Amoebozoa - biodiversity - Cercozoa - documentation - Liceida - Mycobiota Physarum

\section{Introduction}

For Egypt, only very few comprehensive assessments of local fungi have been published (e.g. El-Abyad and Abu-Taleb 1993; El-Abyad 1997; Abdel-Azeem, 2010). Documentation of the Egyptian fungi may be dated back to 4500 B.C., when ancient Egyptians produced a number of hieroglyphic reliefs of plants (many of which are psychedelic) on walls and within texts throughout Egypt (Abdel-Azeem 2010). Abdel-Azeem has traced the history of scientific work with fungi in Egypt from its earliest beginnings, almost 200 years ago, through to the present day and published a full review of the history of mycology in Egypt, together with updated assessment of 2281 species of fungi for the country, and an expectation of future perspectives for mycology in Egypt.

Myxomycetes (commonly called slime molds) are a cosmopolitan group of organisms that can be found in a variety of habitats including well-manicured lawns and flower beds, and moist places, especially on old wood and other plant material undergoing decomposition. Myxomycetes also are common on dung, and a few species may be restricted to this substratum. Another more recently recognized, specialized niche is represented by dead branches attached to living trees. The important taxonomic treatises available on slime moulds include Martin and Alexopoulos (1969), Alexopoulos $(1973,1978)$ and Farr (1976).

Taxonomically, the myxomycetes have been classified in the kingdom Plantae (class Myxomycota) and the kingdom Animalia (class Mycetozoa), but members of the group are presently classified as Protozoans. Although they are not fungi, myxomycetes traditionally have been studied by mycologists (Hawksworth 1991, Everhart and Keller 2008, Rojas and Stephenson 2008). 
The kingdom Protozoa contains a heterogeneous assemblage of organisms that do not fit into the other kingdoms. The 115000 known species are extremely diverse in their cell structure, patterns of nutrition, metabolic needs, reproduction, and habitat. Protozoan fungal analogues are heterotrophic and most are decomposers that feed on dead plants and animals by endocytosis (Kendrick 2000). According to Kirk et al. (2008) there are about 1165 fungal protozoan analogues described.

Checklists are important tools in taxonomy, systematics and conservation (Söderström et al. 2007, 2008). In spite of that, several important areas lack recent checklists, including Egypt. Information about Egyptian protozoan fungus-like analogues are very rare and limited because members of the group were either overlooked during investigations or have never been the sole target of any previous investigation (Lado 1994, Stephenson and Stempen 1994) except for the pioneer study of Abdel-Raheem (2002) on those of Upper Egypt.

Following a recent publication on the assessment of total fungi in Egypt (Abdel-Azeem 2010), this paper continues to close the gaps in knowledge on the fungi diversity of Egypt by providing a comprehensive checklist of protozoan fungal analogues.

\section{Materials \& Methods}

\section{Study area}

Egypt's geographical position at the junction between two large continents (Africa and Asia), and its inclusion as part of the Mediterranean basin, has indelibly influenced both the people and the biota of the country socially, economically and biologically. Egypt is part of the Sahara of North Africa and has an area of about $1 \mathrm{M} \mathrm{km}^{2}$, divided by the River Nile into a western part including the Libyan Desert $\left(681000 \mathrm{~km}^{2}\right)$ and an eastern part comprising the Eastern Desert $\left(223000 \mathrm{~km}^{2}\right)$, and the Sinai Peninsula $\left(61000 \mathrm{~km}^{2}\right)$. The Nile basin, comprising the valley in the south (Upper Egypt) and Nile delta in the north (Lower Egypt), forms a riparian oasis $\left(40000 \mathrm{~km}^{2}\right)$ that constitutes the densely inhabited farmlands of Egypt (Fig. 1).

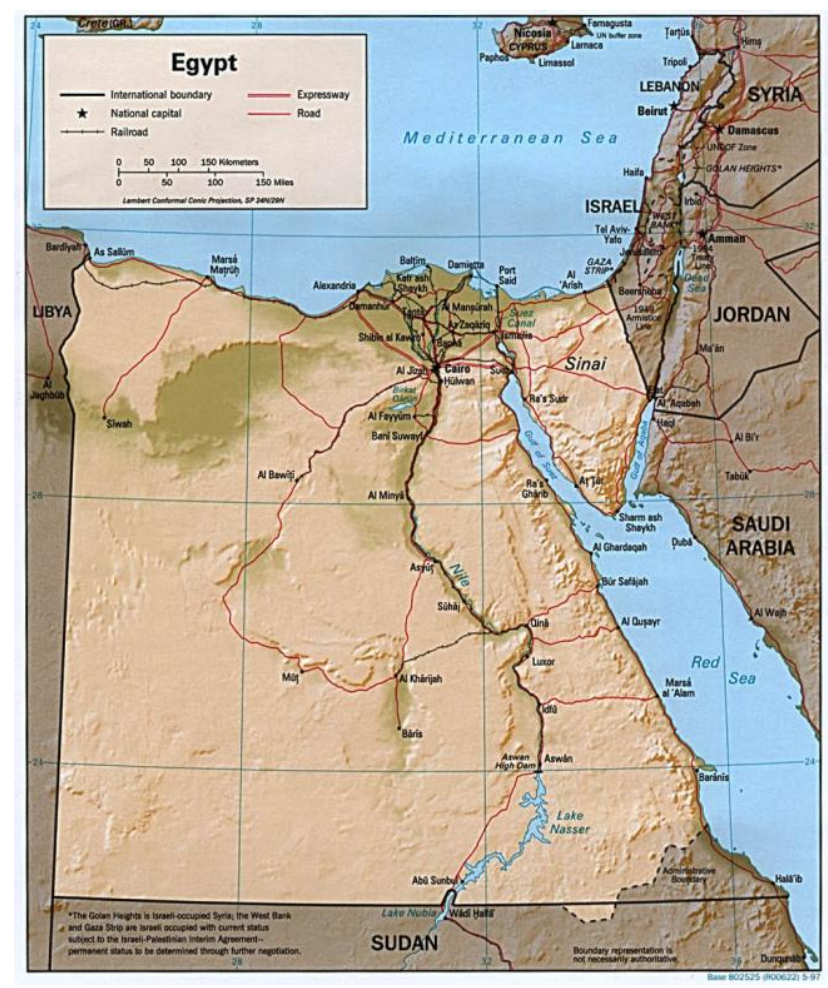

Fig. 1 - Map of Egypt. 


\section{Data Collection}

The species listed here were compiled mainly from the studies of Massee (1892), Olive and Stoianovitch (1969), El-Eliasson and Lundqvist (1979), Hissy and Khallil (1991), Abdel-Raheem (2002, 2006), Tohamy (2008), Farghaly (2008) and Ndiritu et al. (2009), which collectively cover many different habitats in Egypt. A main list of Egyptian protozoan fungal analogues has been developed and the taxa are given in alphabetical order. The names of authors of fungal taxa are abbreviated according to Kirk and Ansell (1992) and Kirk et al. (2008). Species of each group were given in a taxonomic sequence and accepted names are highlighted in bold. The systematic arrangement in the present list follows the latest system of classification appearing in the $10^{\text {th }}$ edition of Anisworth and Bisby's Dictionary of the Fungi (Kirk et al. 2008). Name corrections, authorities, and taxonomic assignments of all taxa reported in this work were checked against the Index Fungorum database (www. indexfungorum.org) and a provisional key to the identification of reported taxa is given.

\section{Results}

A total of 61 species, including 3 varieties and 1 forma specials, within 29 genera, 13 families, 7 orders, 3 classes and 2 phyla are included in this annotated list of protozoan fungal analogues from Egypt (Table 1). These species of protozoan fungal analogues were reported from decaying wood, leaves, dead bark, the bark of living plants, dung, aquatic canals and plant roots. Species are arranged alphabetically under each taxonomic rank. Liceida is the dominant order with three families, Stemonitaceae is the dominant family with 6 genera and Physarum is the dominant genus with at least nine species in Egypt. The family Physaraceae is the largest, with 12 species, followed by the Didymiaceae (11 species) and Stemonitidaceae (10 species), while Protosteliaceae. Cribrariaceae, Clastodermataceae and Echinosteliaceae are represented by only one species each.

Table 1 Protozoan fungal analogues known in Egypt.

\begin{tabular}{llllll}
\hline Orders & Families & Genera & Species & Variety & Forms \\
\hline Trichiida & Arcyriaceae & 1 & 6 & - & - \\
& Trichiaceae & 4 & 7 & - & - \\
Protostelida & Ceratiomyxaceae & 1 & 2 & 1 & - \\
& Protosteliaceae & 1 & 1 & - & - \\
Liceida & Cribrariaceae & 1 & 1 & - & - \\
& Tubiferaceae & 2 & 4 & & \\
Echinostelida & Liceaceae & 1 & 2 & - & - \\
& Clastodermataceae & 1 & 1 & - & - \\
Physarida & Echinosteliaceae & 1 & 1 & & \\
\multirow{2}{*}{ Stemonitida } & Didymiaceae & 3 & 11 & 1 & - \\
Plasmodiophorida & Physaraceae & 4 & 12 & 1 & - \\
& Stemonitidaceae & 6 & 10 & - & - \\
& Plasmodiophoridae & 3 & 3 & - & 1 \\
\hline
\end{tabular}

\section{Checklist of Protozoan fungal analogues reported in Egypt}

The genera and species are given in alphabetical order, with information on the substrate and areas of Egypt where these the former were reported.

Kingdom: Protozoa

Phylum 1: Amoebozoa

Infraphylum: Mycetozoa

Class 1: Myxogastrea 
Subclass: Incertae sedis

Order 1: Echinostelida

Family 1: Clastodermataceae

Clastoderma debaryanum A. Blytt 1880

Substrate: Decaying wood and bark.

Distribution: Rare occurrence in Assiut, Sohag and Qena.

Reported by Abdel-Raheem (2002) and Ndiritu et al. (2009)

Family 2: Echinosteliaceae

Echinostelium minutum de Bary 1873

Substrate: Decaying wood and bark.

Distribution: Occasional occurrence in Assiut, Sohag and Qena.

Reported by Abdel-Raheem (2002) and Ndiritu et al. (2009)

Order 2: Liceida

Family 3: Cribrariaceae

Cribraria violacea $\operatorname{Rex} 1891$

Substrate: Decaying wood and leaves.

Distribution: Occasional occurrence in Qena.

Reported by Farghaly (2008)

Family 4: Liceaceae

Licea biforis Morgan 1893

Substrate: Decaying wood and leaves.

Distribution: Occasional occurrence in Assiut.

Reported by Abdel-Raheem (2002), Farghaly (2008) and Ndiritu et al. (2009)

Licea operculata (Wingate) G.W. Martin 1942

Substrate: Decaying wood and leaves.

Distribution: Occasional occurrence in Sohag and Qena.

Reported by Farghaly (2008)

Family 5: Tubiferaceae

Lycogala conicum Pers. 1801 [as 'conica']

Substrate: Decaying wood.

Distribution: Rare occurrence in Assiut, Sohag and Qena.

Reported by Abdel-Raheem (2002) and Ndiritu et al. (2009)

Lycogala epidendrum (J.C. Buxb. ex L.) Fr. 1829

Substrate: Decaying wood and Bark.

Distribution: Abundant occurrence in El-Minia, Assiut, Sohag, Qena and Aswan.

Reported by Abdel-Raheem (2002), Farghaly (2008) and Ndiritu et al. (2009)

Lycogala exiguum Morgan 1893

Substrate: Decaying wood and Bark.

Distribution: Occasional occurrence in Assiut.

Reported by Farghaly (2008)

Tubifera ferruginosa (Batsch) J.F. Gmel. 1791

Substrate: Decaying wood.

Distribution: Common in Delta.

Reported by Abdel-Raheem (2006) 
Order 3: Physarida

Family 6: Didymiaceae

Diderma chondrioderma (de Bary \& Rostaf.) Kuntze 1898

Substrate: Decaying wood, bark and leaves.

Distribution: Occasional in El-Minia, Assiut and Qena.

Reported by Farghaly (2008)

Diderma effusum (Schwein.) Morgan 1894

Substrate: Decaying wood and bark.

Distribution: Occasional in El-Minia and Sohag.

Reported by Abdel-Raheem (2002), Farghaly (2008) and Ndiritu et al. (2009)

Diderma hemisphaericum (Bull.) Hornem. 1829

Substrate: Decaying wood, bark and leaves.

Distribution: Abundant in Assiut, Sohag and Qena.

Reported by Farghaly (2008)

Didymium clavus (Alb. \& Schwein.) Rabenh. 1844

Substrate: Decaying wood and leaves.

Distribution: Rare occurrence in Egypt.

Reported by Massee (1892)

Didymium floccosum G.W. Martin, K.S. Thind \& Rehill 1959

Substrate: Decaying wood.

Distribution: Rare occurrence in Sohag.

Reported by Farghaly (2008)

Didymium iridis (Ditmar) Fr. 1829

Substrate: Decaying wood.

Distribution: Rare occurrence in Sohag.

Reported by Farghaly (2008)

Didymium melanospermum (Pers.) T. Macbr. 1899

Substrate: Decaying wood and leaves.

Distribution: Common occurrence in Assiut, Sohag and Qena.

Reported by Abdel-Raheem (2002), Farghaly (2008) and Ndiritu et al. (2009)

Didymium melanospermum var. minus (Lister) G. Lister 1925

Substrate: Decaying wood and leaves.

Distribution: Occasional occurrence in El-Minia, Sohag and Aswan.

Reported by Farghaly (2008)

Didymium nigripes (Link) Fr. 1829

Substrate: Decaying wood.

Distribution: Occasional occurrence in El-Minia and Sohag.

Reported by Farghaly (2008)

Didymium squamulosum (Alb. \& Schwein.) Fr. 1818

Substrate: Decaying wood and bark.

Distribution: Common occurrence in Assiut, Sohag and Qena.

Reported by Farghaly (2008) 
Lepidoderma tigrinum (Schrad.) Rostaf. 1873

Substrate: Decaying wood.

Distribution: Occasional occurrence in Sohag and Qena.

Reported by Abdel-Raheem (2002), Farghaly (2008) and Ndiritu et al. (2009)

Family 7: Physaraceae

Badhamia apiculospora (Härk.) Eliasson \& N.Lundq.

Substrate: Decaying wood.

Distribution: Rare in Egypt.

Reported by Eliasson and Lundqvist (1979)

Badhamia versicolor Lister 1901

Substrate: Decaying wood.

Distribution: Rare in Sohag.

Reported by Farghaly (2008)

Fuligo septica (L.) F.H. Wigg. 1780

Substrate: Decaying wood.

Distribution: Common in Sohag.

Reported by Farghaly (2008)

Physarella oblonga (Berk. \& M.A. Curtis) Morgan 1896

Substrate: Decaying wood.

Distribution: Abundant in El-Minia, Assiut, Sohag, Qena and Aswan.

Reported by Abdel-Raheem (2002), Farghaly (2008) and Ndiritu et al. (2009)

Physarella oblonga (Berk. \& M.A. Curt.) Morgan (Berk. \& Curt.) Morgan f. alba Alexop. 1964

Substrate: Decaying wood, bark and leaf litter.

Distribution: Abundant in El-Minia, Assiut, Sohag, Qena and Aswan.

Reported by Farghaly (2008)

Physarum diderma Rostaf. 1875

Substrate: Decaying wood.

Distribution: Occasional occurrence in Assiut and Sohag.

Reported by Farghaly (2008)

Physarum didermoides (Ach. ex Pers.) Rostaf. 1875

Substrate: Decaying wood.

Distribution: Occasional occurrence in El-Minia, Assiut and Sohag.

Reported by Farghaly (2008)

Physarum globuliferum (Bull.) Pers. 1801

Substrate: Decaying wood and bark.

Distribution: Occasional occurrence in Egypt Assiut, Sohag and Qena.

Reported by Abdel-Raheem (2002) and Ndiritu et al. (2009)

Physarum melleum (Berk. \& Broome) Massee 1892

Substrate: Decaying wood and bark.

Distribution: Occasional occurrence in Sohag.

Reported by Farghaly (2008) 
Physarum psittacinum Ditmar 1817

Substrate: Decaying wood and bark.

Distribution: Occasional occurrence in Sohag.

Reported by Farghaly (2008)

Physarum pusillum (Berk. \& M.A. Curtis) G. Lister

Substrate: Decaying wood.

Distribution: Occasional occurrence in El-Minia and Qena.

Reported by Farghaly (2008)

Physarum utriculare (Bull.) Chevall. 1826

Substrate: Decaying wood and bark.

Distribution: Occasional occurrence in Assiut, Sohag and Qena.

Reported by Abdel-Raheem (2002) and Ndiritu et al. (2009), as Badhamia utricularis

(Bull.) Berk. 1852

\section{Physarum virescens Ditmar 1817}

Substrate: Decaying wood, Bark and leaves.

Distribution: Occasional occurrence in Assiut, Sohag and Qena.

Reported by Abdel-Raheem (2002) and Ndiritu et al. (2009)

Physarum viride var. viride (Bull.) Pers. 1795

Substrate: Decaying wood.

Distribution: Rare occurrence in Assiut, Sohag and Qena.

Reported by Abdel-Raheem (2002) and Ndiritu et al. (2009)

Order 4: Stemonitida

Family 8: Stemonitidaceae

Collaria arcyrionema (Rostk.) Nann.-Bremek. ex Lado 1991.

Substrate: Decaying wood.

Distribution: Rare occurrence in Sohag, Qena and Aswan.

Reported by Farghaly (2008), as Lamproderma arcyrionema Rostaf. 1875

Comatricha laxa Rostaf. 1875

Substrate: Decaying wood and bark.

Distribution: Occasional occurrence in Qena and Aswan.

Reported by Farghaly (2008)

Comatricha nigra (Pers.) J. Schröt. 1886

Substrate: Decaying wood and bark.

Distribution: Common occurrence in El-Minia, Assiut, Sohag and Qena.

Reported by Farghaly (2008)

Comatricha pulchella (C. Bab.) Rostaf. 1876

Substrate: Decaying wood and bark.

Distribution: Occasional occurrence in Sohag and Qena.

Reported by Farghaly (2008)

Diachea bulbillosa (Berk. \& Broome) Lister 1898

Substrate: Decaying wood.

Distribution: Rare occurrence in Sohag.

Reported by Farghaly (2008) 
Lamproderma sauteri Rostaf. 1875

Substrate: Decaying wood and dead leaves.

Distribution: Rare occurrence in Assiut.

Reported by Farghaly (2008)

Lamproderma scintillans (Berk. \& Broome) Morgan 1894

Substrate: Decaying wood.

Distribution: Occasional occurrence in Sohag.

Reported by Abdel-Raheem (2002), Farghaly (2008) and Ndiritu et al. (2009)

Stemonitis axifera (Bull.) T. Macbr. 1889

Substrate: Decaying bark and dead bark of a living tree.

Distribution: Occasional occurrence in El-Minia and Sohag.

Reported by Farghaly (2008)

Stemonitis flavogenita E. Jahn 1904

Substrate: Decaying bark and dead bark of living tree.

Distribution: Occasional occurrence in Sohag.

Reported by Farghaly (2008)

Stemonitis splendens Rostaf. 1875

Substrate: Decaying wood and bark.

Distribution: Occasional occurrence in Aswan.

Reported by Farghaly (2008)

Symphytocarpus longus (Peck) Nann.-Bremek. 1975

Substrate: Decaying wood.

Distribution: Rare occurrence in Sohag.

Reported by Farghaly (2008), as Stemonaria longa (Peck) Nann.-Bremek., Y. Yamam. \& R. Sharma 1983

Order 5: Trichiida

Family 9: Arcyriaceae

Arcyria cinerea (Bull.) Pers. 1801

Substrate: Wood and bark.

Distribution: Abundant in El-Minia, Assiut, Sohag, Qena and Aswan.

Reported by Abdel-Raheem (2002), Farghaly (2008) and Ndiritu et al. (2009)

Arcyria denudata (L.) Wettst. 1886

Substrate: Decaying wood.

Distribution: Occasional occurrence in Sohag and Qena.

Reported by Farghaly (2008)

Arcyria globosa Schwein. 1822

Substrate: Decaying wood and leaves.

Distribution: Occasional occurrence in Assiut and Sohag.

Reported by Farghaly (2008)

Arcyria major (G. Lister) Ing 1967

Substrate: Decaying wood.

Distribution: Occasional occurrence in El-Minia and Assiut.

Reported by Farghaly (2008) 
Arcyria nigella Emoto 1977

Substrate: Decaying wood.

Distribution: Occasional occurrence in Assiut and Qena.

Reported by Farghaly (2008)

Arcyria versicolor W. Phillips 1877

Substrate: Decaying wood.

Distribution: Rare in Assiut, Sohag and Qena.

Reported by Abdel-Raheem (2002)

Family 10: Trichiaceae

Hemitrichia calyculata (Speg.) M.L. Farr 1974

Substrate: Decaying wood.

Distribution: Abundant occurrence in El-Minia, Assiut, Sohag and Qena.

Reported by Farghaly (2008)

Metatrichia vesparium (Batsch) Nann.-Bremek. ex G.W. Martin \& Alexop. 1969

Substrate: Decaying wood.

Distribution: Rare occurrence in Assiut, Sohag and Qena.

Reported by Abdel-Raheem (2002) and Ndiritu et al. (2009)

Perichaena chrysosperma (Curr.) Lister 1894

Substrate: Decaying wood, bark, dead bark of living plants and dung.

Distribution: Abundant in El-Minia, Assiut, Sohag, Qena and Aswan.

Reported by Farghaly (2008)

Perichaena corticalis (Batsch) Rostaf. 1875

Substrate: Decaying wood, bark, dead bark of living plants and dung.

Distribution: Occasional in Sohag and Qena.

Reported by Farghaly (2008)

Perichaena depressa Lib. 1837

Substrate: Decaying wood.

Distribution: Abundant in El-Minia, Assiut, Sohag, Qena and Aswan.

Reported by Abdel-Raheem (2002), Farghaly (2008) and Ndiritu et al. (2009)

Perichaena vermicularis (Schwein.) Rostaf. 1876

Substrate: Decaying wood, bark and leaf litter.

Distribution: Occasional in Sohag and Aswan.

Reported by Farghaly (2008)

Trichia favoginea (Batsch) Pers. 1794

Substrate: Decaying wood.

Distribution: Rare occurrence in Assiut, Sohag, Qena and common in Delta.

Reported by Abdel-Raheem $(2002,2006)$ and Ndiritu et al. (2009)

Class 2: Protostelea

Subclass: Incertae sedis

Order 6: Protostelida 
Family 11: Ceratiomyxaceae

Ceratiomyxa fruticulosa (O.F. Müll.) T. Macbr. 1899

Substrate: Decaying wood.

Distribution: Abundant occurrence in El-Minia, Assiut, Sohag, Qena and Aswan.

Reported by Abdel-Raheem (2002), Farghaly (2008) and Ndiritu et al. (2009)

Ceratiomyxa fruticulosa var. fruticulosa (O.F. Müll.) T. Macbr. 1899

Substrate: Decaying wood.

Distribution: Common occurrence in El-Minia, Assiut, Sohag, Qena and Aswan.

Reported by Farghaly (2008)

Family 12: Protosteliaceae

Protostelium irregulare L.S. Olive \& Stoian. 1969 [as 'irregularis']

Substrate: on dead capsules, pods, flowers, leaves, and old berries still attached to the plants, occasionally in soil and humus.

Distribution: Fairly common in Egypt.

Reported by Olive and Stoianovitch (1969)

Phylum 2: Cercozoa

Infraphylum: Endomyxa

Class 3: Phytomyxea

Subclass: Incertae sedis

Order 7: Plasmodiophorida

Family 13: Plasmodiophoridae

Plasmodiophora brassicae Woronin 1877

Substrate: Brassica oleracea L. var. botrytis L.

Distribution: Occasional occurrence in Egypt.

Reported by Crête and Chiang (1980)

Spongospora subterranea f.sp. subterranea J.A. Toml. 1892

Substrate: Potato

Distribution: Occasional occurrence in Behira, Ismailia and Sharkiya.

Reported by Tohamy (2008)

Woronina polycystis Cornu 1872

Substrate: Water and submerged mud.

Distribution: Rare frequency of occurrence in El-Ibrahimia Canal.

Reported by El-Hissy and Khallil (1991) 


\section{Key to genera of protozoan fungal analogues in Egypt}

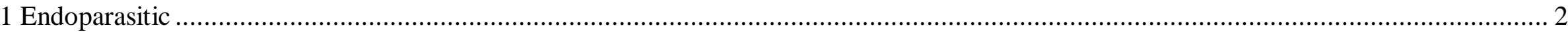

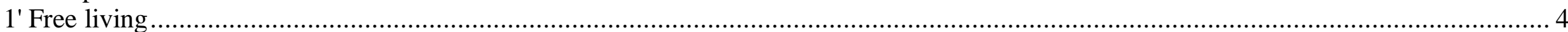

2 Resting spores are single (unattached) although produced in large masses................................................................Plasmodiophora

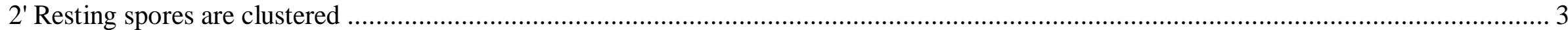

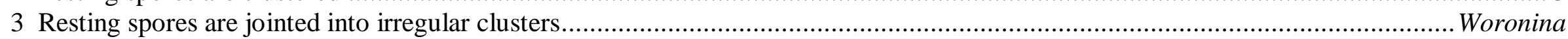

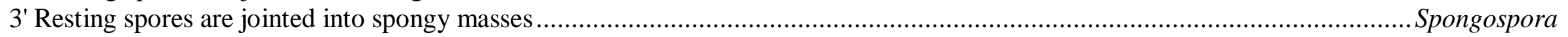

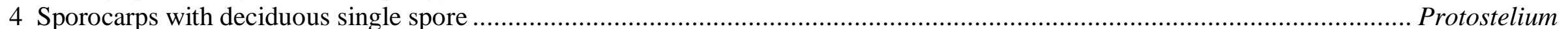

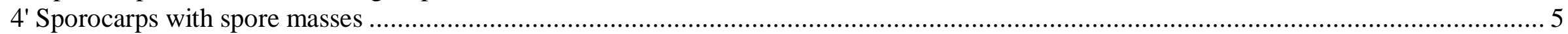

5 Spores borne singly on thin stalks on the outside of the fruitbody. Sporocarps of branched columns, occasionally coaleshed into honeycomb like cushions. Mostly white, occasionally cream or pale yellowish ................................................................................. Ceratiomyxa

5' Spores borne in masses, within various types of sporophores, peridium persistent or early evanescent ............................................. 6 6 Spores pallid, bright coloured, ferruginous, purple-brown, or black, assimilative stage of various types but never a true aphanoplasmodium 7

6' Spores violet-brown, lilac, ferruginous, assimilative stage an aphanoplasmodium ...................................................................... 24

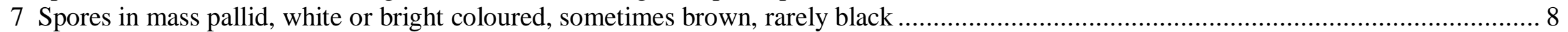

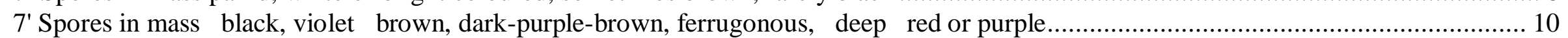

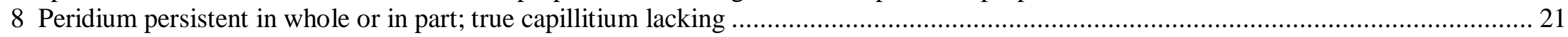

$8^{\prime}$ True capillitium typically present; if lacking the peridium early fugacion and sporocarps minute .................................................... 9

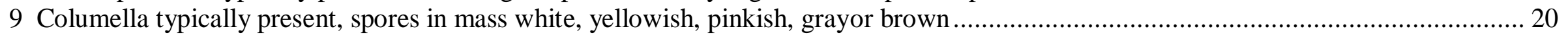

9' Columella absent, spores in mass white, ochraceous, yellow, orange, or red rarely black ............................................................ 16

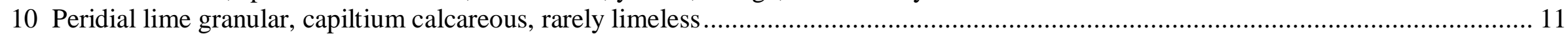

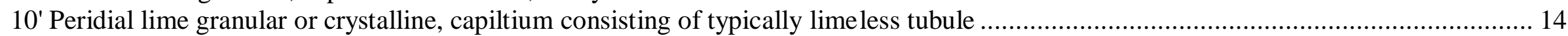

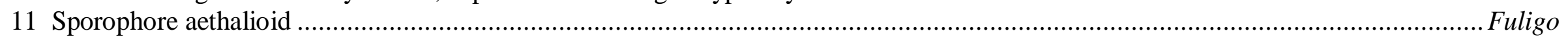

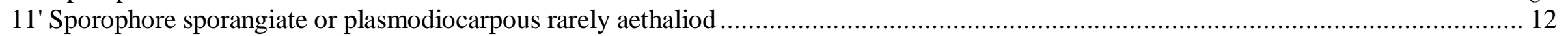

12 Sporophores with calcerous, platelike, internal septa or spike-like trabeculae ............................................................Physarella

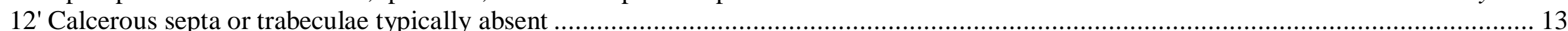

13 Capillitium a network of calcerous tubules connected by very short limeless strands......................................................... Badhamia

13' Capillitium a network of limeless tubules, connectinge calcerous nodes with irregular or lobate dehiscence .............................Physarum

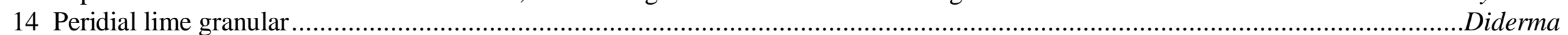

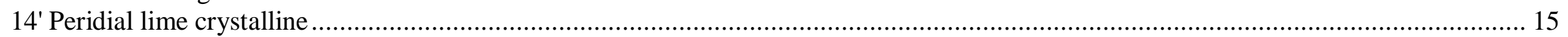

15 Lime crystals scattered or united into a layer but not forming scales ......................................................................... Didymium

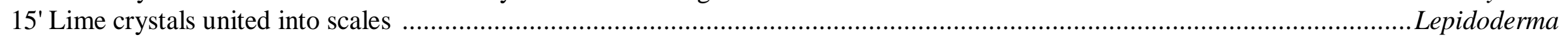

16 Capillitial threads variously ornamented or nearly smooth, without well-defined spiral bands 
16' Capillitial threads bearing conspicuous spirals.....

17 Capillitium of short or long elaters, the later rarely united to form a net

Perichoena

17' Capillitium threads typically united into a network

Arcyria

18 Capillitium forming a tight network

Hemitrichia

18' Capillitium in the form of short or long, free elaters 19

19 Sporangia opening by a performed lid, elaters conspicuously spiny

Metatricha

19 ' Sporangia usually dehiscing irregularly, elaters not prominently spiny

Trichia

20 Spores in mass white, cream-colored, yellow, pink, gray or rarely pink-brown; peridium delicate, evanescent at an early stage

20' Spores in mass brown, peridium persistent

Echinostelium

21 Sporophores sporangiate; pseudocapillitium and dictydine granules lacking.

Clastoderma

21' Sporophores a pseudoaethalium, individual sporocarps clearly discernible

Licea

21" Sporophores sporangiate; or aethaloid; pseudocapillitium or dictydine granules may be present

Symphytocarpus

22 Fruitbody a spherical- to cushion-shaped aethalium

22

22 ' Fruitbody a \pm cushion-shaped, individual sporocarps partly free, the shared peridial walls partly persistent, honeycomb-shaped. Spores rusty brown to cinnamon

23 Dictydine granules lacking, sporophore a true aethalium

Tubifera

23' Dictydine granules present, sporophore sporangiate

Lycogala

24 Lime present on some part of the fruitification, sometimes scanty in the form of crystals at the base of the sporangium

Cribraria

24' Lime totally absent.

25 Peridium tough, metallic, long persistent

Diachea

25

25' Peridium early evanescent or, if persistent, thin, membranous, delicate

Lamproderma

26 Columella absent.

Collaria

26' Columella present

27 Capillitium terminating in a surface net with no or few free ends

Stemonitis

27 ' Surface net absent or, if present, usually with may free ends

Comatricha 
The present list is concerned the only one of Egyptian protozoan fungal analogues reported from decaying wood, leaves, dead bark, the bark of living plants, dung, aquatic canals and plant roots. Therefore, it should be mentioned here that, although the present study will add some new data to our information concerning the Egyptian fungi, this updated check-list must be considered as a provisional one always waiting for continuous supplementation.

\section{References}

Abdel-Azeem AM. 2010 - The history, fungal biodiversity, conservation, and future perspectives for mycology in Egypt. IMA Fungus 1: 123-142.

Abdel-Raheem AM. 2006 - Myxomycetes from Delta Region in Egypt. $8^{\text {th }}$ International Mycological Congress, 21 - 25 August 2006, Cairns Convention Centre, Queensland, Australia, abstract book, 346.

Abdel-Raheem AM. 2002 - Myxomycetes from Upper Egypt. Microbiol. Res. 157, 47-67.

Alexopoulos CJ. 1973 - Myxomycetes. In: the fungi, an advanced Treatise, vol. IVB (Eds: Anisworth, G. C.; Sparrow, F. K., Sussman, A. S.). Academic Press, New York, 39-60.

Alexopoulos CJ. 1978 - The Evolution of the Taxonomy of the Myxomycetes; p. 1-8. In C. V. Subramanian (ed.) Proceedings Intern. Sym. Taxon. Fungi. Part I, University of Mardas.

Crête R, Chiang MS. 1980 - Screening Brassicas for resistance to clubroot, Plasmodiophora brassicae Wor. Can. Plant Dis. Surv. 60:1, 17-19.

El-Abyad MS. 1997 - Biodiversity of Fungal Biota in Egypt. Up-dated check-list. [Publication of National Biodiversity Unit No. 7.] Egyptian Environmental Affairs Agency.

El-Abyad MS, Abu-Taleb A. 1993 - II-Soil Fungi. Ecology of fungal flora. In: Publication of National Biodiversity Unit. No. 1. Habitat Diversity: 237-262. Egyptian Environmental Affairs Agency, Egypt.

El-Hissy FT, Khallil AM. 1991 - Distribution and Seasonal Occurrence of Aquatic Phycomycetes in Water and Submerged Mud in El-Ibrahimia Canal (Upper Egypt). Journal of Islamic Academy of Sciences 4:4, 311-316.

Eliasson U, Lundqvist N. 1979 - Fimicolous myxomycetes. Bot. Not. 132, 551-568.

Everhart SE, Keller HW. 2008 - Life history strategies of corticolous myxomycetes: the life cycle, fruiting bodies, plasmodial types, and taxonomic orders. Fungal Diversity 29, 1-16.

Farghaly MSEB. 2008 - Biodiversity and some physiological studies of Myxomycetes in Upper Egypt. MSc. Thesis, Faculty of Science, Sohage University, Egypt.

Farr ML. 1976 - Myxomycetes. Flora Neotropica 16, 1-305.

Hawksworth DL. 1991 - The fungal dimension of biodiversity: magnitude, significance, and conservation. Mycological Research 95, 641-655.

Kendrick B. 2000 - The Fifth Kingdom. 3rd edn. Focus Publishing, Newbury. Massachsetts, USA.

Kirk PM, Ansell AE. 1992 - Authors of Fungal Names. Kew: CAB International, 95 p.

Kirk P, Cannon PF, Minter DW, Stalpers JA. 2008 - Ainsworth \& Bisby's Dictionary of the Fungi. $10^{\text {th }}$ edn. CAB International, Wallingford, UK.

Lado C. 1994 - A checklist of Myxomycetes of the Mediterranean countries. Mycotaxon 52, $117-$ 185.

Martin GW, Alexopoulos CJ. 1969 - The myxomycetes. Iowa City: University of Iowa Press. 561 p.

Massee G. 1892 - A monograph of the Myxogastres. Methuen \& Co. London.

Ndiritu GG, Winsett KE, Spiegel FW, Stephenson SL. 2009 - A checklist of African myxomycetes. Mycotaxon 107, 353-356.

Olive LS, Stoianovitch 1969 - Monograph of the genus Protostelium. Amer. J. Bot. 56:9, 979-988.

Rojas C, S. Stephenson L. 2008 - Myxomycete ecology along an elevation gradient on Cocos Island, Costa Rica. Fungal Diversity 29, 117-127. 
Söderström L, Hagborg A, von Konrat M, Renner MAM. 2008 - Early Land Plants Today: Liverwort checklist of checklists. Fieldiana, Botany, n.s. 47, 105-130.

Söderström L, Urmi E, Váňa J. 2007 - The distribution of Hepaticae and Anthocerotae in Europe and Macaronesia- Update 1-427. Cryptogamie, Bryologie 28, 299-350.

Stephenson SL, Stempen H. 1994 - Myxomycetes: a handbook of slime molds. Oregon: Timber Press. 200p.

Tohamy A. 2008 - The status of powdery scab disease on potatoes in Egypt. APS Centennial Meeting, History of Excellence Future of Promise. The American Phytopathological Society. July 26-30, 2008, Phytopathology 98,S156. 